\title{
PENGARUH MODEL PEMBELAJARAN INKUIRI TERHADAP KETERAMPILAN BERPIKIR KRITIS SISWA KELAS XI MIA MAN 2 MATARAM
}

\section{EFFECTS OF INQUIRY LEARNING MODEL ON STUDENTS' CRITICAL THINKING SKILLS OF GRADE XI MIA MAN 2 MATARAM}

\author{
Maryam*, Kusmiyati, I Wayan Merta, I Putu Artayasa \\ Program Studi Pendidikan Biologi, Jurusan Pendidikan MIPA, FKIP Universitas Mataram \\ Jalan Majapahit No. 62, Mataram NTB 83125 Telp. (0370) 62387 \\ *Email: iyamy197@gmail.com
}

Diterima: 21 April 2019. Disetujui: 20 Agustus 2019. Dipublikasikan: 30 September 2019

\begin{abstract}
Abstrak. Pelaksanaan pembelajaran biologi masih kurang melibatkan proses berpikir siswa. Proses berpikir sangat penting untuk melatih keterampilan berpikir tingkat tinggi, salah satunya berpikir kritis, yang merupakan salah satu kecakapan berpikir dalam pembelajaran abad 21. Salah satu model pembelajaran yang diamanatkan dalam Kurikulum 2013 adalah inkuiri. Penelitian ini bertujuan untuk mengetahui pengaruh model pembelajaran inkuiri terhadap keterampilan berpikir kritis siswa kelas XI MIA MAN 2 Mataram. Jenis penelitian ini adalah Quasi Experimental dengan desain Non-Equivalent Control Group Design. Populasi penelitian adalah seluruh siswa kelas XI MIA di MAN 2 Mataram, dengan sampel kelas XI MIA 1 dan XI MIA 2 yang ditentukan dengan teknik purposive sampling. Data dikumpulkan dengan instrumen tes kemudian dianalisis dengan uji anakova (analisis kovarian). Hasil uji anakova menunjukkan adanya perbedaan keterampilan berpikir kritis antara siswa kelas eksperimen dengan siswa kelas kontrol $(\mathrm{p}=0,00<0,05)$. Berdasarkan hasil tersebut maka $\mathrm{H}_{0}$ ditolak dan $\mathrm{H}_{\mathrm{a}}$ diterima, dengan demikian model pembelajaran inkuiri berpengaruh terhadap keterampilan berpikir kritis siswa kelas XI MIA MAN 2 Mataram tahun ajaran 2019/2020. Kesimpulan dari penelitian ini adalah model pembelajaran inkuiri berpengaruh dalam meningkatkan keterampilan berpikir kritis siswa.
\end{abstract}

Kata kunci: model pembelajaran inkuiri, keterampilan berpikir kritis

ABSTRACT.Biology learning implementation only involves a little portion of students thinking process. Thinking process is very important to train students' high-order thinking skills, including critical thinking as one of the important skills in the $21^{\text {st }}$ century. One of the learning models mandated in Curriculum 2013 is inquiry. This research aims to determine the effects of inquiry learning model on critical thinking skills of Grade XI Mathematics and Sciences of Mataram State Islamic Senior High School 2.This research was a Quasi Experiment with Non-Equivalent Control Group Design. The population of this research was all students of Grade XI Mathematics and Sciences ofMataram State Islamic Senior High School 2, with the sample of Grade XI Mathematics and Sciences Class 1 and 2 which was determined by purposive sampling. The data was collected using a test instrument and then analyzed by ancova (analysis of covariance). Ancova results indicate the differences in students' critical thinking skills between experimental class and control class $(p=0.00<0.05)$. Based on the result, $\mathrm{H}_{0}$ is rejected and $\mathrm{H}_{\mathrm{a}}$ is accepted. Therefore, inquiry learning model affects the students' critical thinking skills of Grade XI Mathematics and Sciences. In conclusion, inquiry learning model can increase students' critical thinking skills.

Keywords: inquiry learning model, critical thinking skills

\section{PENDAHULUAN}

Berpikir kritis merupakan salah satu dari keterampilan berpikir tingkat tinggi. Berpikir kritis adalah cara berpikir tingkat tinggi atau berpikir dengan menghasilkan kemampuan mengidentifikasi suatu masalah, menganalisis, dan menentukan langkah-langkah pemecahan, membuat kesimpulan serta mengambil keputusan. Berpikir kritis sangat dibutuhkan siswa untuk mempersiapkan dirinya menghadapi kemajuan ilmu pengetahuan dan teknologi di abad 21. Oleh karena itu, untuk mengantisipasi kemajuan ilmu pengetahuan dan teknologi, perlu dilakukan berbagai pembaharuan dan perbaikan dalam dunia pendidikan agar tercapainya keberhasilan dalam proses pembelajaran [1].

Berdasarkan hasil observasi dan wawancara terhadap siswa kelas XI MIA di MAN 2 Mataram semester ganjil tahun ajaran 2018/2019, bahwa kegiatan pembelajaran biologi berlangsung cukup baik. Guru banyak memberikan siswa tugas kelompok sehingga pembelajaran melibatkan kegiatan diskusi, tetapi siswa sangat berpatokan pada buku teks yang ada saja dan tidak banyak mengeksplor sumber lain. Siswa lebih sering mempelajari biologi dengan metode ceramah, dengan mendengarkan penjelasan guru di kelas. Menurut wawancara dengan guru mata pelajaran 
biologi bahwa siswa hanya mengetahui biologi hanya ilmu hafalan yang berpatokan pada buku referensi semata. Siswa bersikap pasif, sehingga proses pembelajaran tersebut tidak banyak melibatkan proses berpikir termasuk berpikir kritis.

Setyorini, Sukiswo, dan Subali [2] menjelaskan bahwa dalam penerapan model DI (direct instructional), keterampilan berpikir kritis siswa cenderung rendah karena siswa bersikap pasif dan hanya mendengarkan penjelasan dari guru, proses pembelajaran hanya mengandalkan ingatan saja dan tidak dapat mengaplikasikan konsep dalam dunia nyata. Sesuai dengan hasil penelitian oleh Royani, Mirawati, dan Jannah [3] bahwa siswa yang diberikan perlakuan berupa model pembelajaran langsung memiliki keterampilan berpikir kritis dan proses sains yang lebih rendah dibandingkan siswa yang dibelajarkan dengan model pembelajaran berbasis praktikum. Oleh karena itu, siswa membutuhkan pengalaman belajar yang melibatkan proses berpikir ilmiah dan pengalaman dalam mencari tahu sendiri jawaban dari pertanyaan yang ada.

Penerapan model pembelajaran inkuiri memberikan peluang lebih banyak bagi siswa untuk memperoleh kesempatan mempelajari cara menemukan fakta, konsep, dan prinsip melalui pengalamannya sendiri secara langsung. Dengan demikian, siswa tidak hanya belajar dengan menghafal materi biologi dari buku teks atau dari ceramah guru saja tetapi juga memperoleh kesempatan untuk berlatih dan mengembangkan keterampilan proses, keterampilan berpikir, dan bersikap ilmiah. Jufri [4] menjelaskan bahwa kemampuan bekerja secara ilmiah harus didukung oleh adanya rasa ingin tahu, kemampuan bekerjasama, dan keterampilan berpikir kritis. Beberapa karakteristik orang yang mampu berpikir kritis antara lain ialah memiliki perangkat pikiran tertentu yang dipergunakan untuk mendekati gagasannya dan memiliki motivasi kuat untuk mencari dan memecahkan masalah, serta bersikap skeptis yaitu tidak mudah menerima ide atau gagasan kecuali telah membuktikan sendiri kebenarannya. Berdasarkan uraian di atas penelitian ini bertujuan untuk mengetahui pengaruh model pembelajaran inkuiri terhadap keterampilan berpikir kritis siswa.

\section{METODE PENELITIAN}

Penelitian yang dilakukan merupakan penelitian kuantitatif dengan jenis Quasi Eksperiment (eksperimen semu). Desain penelitian ini adalah Non-Equivalent Control Group Design, dengan menggunakan kelas eksperimen (diterapkan model pembelajaran inkuiri terbimbing) dan kelas kontrol (diterapkan pembelajaran konvensional, berupa metode ceramah).

Penelitian dilaksanakan di MAN 2 Mataram pada semester ganjil tahun ajaran 2019/2020 yakni pada tanggal 22 Juli sampai 9 Agustus 2019. Populasi penelitian ini adalah seluruh siswa kelas XI MIA MAN 2 Mataram tahun ajaran 2019/2020, dengan sampel siswa kelas XI MIA 1 sebagai kelas eksperimen dan kelas XI MIA 2 sebagai kelas kontrol, yang dipilih dengan metode purposive sampling. Variabel bebas dalam penelitian ini adalah model pembelajaran inkuiri, dan variabel terikatnya adalah keterampilan berpikir kritis siswa. Pengumpulan data dilakukan dengan instrumen tes kemudian dianalisis dengan uji anakova (analisis kovarian) dengan bantuan aplikasi SPSS 16.0.

Prosedur penelitian terdiri atas tahap persiapan dan tahap pelaksanaan. Tahap persiapan terdiri atas observasi data sekolah, analisis materi pelajaran biologi, analisis silabus dan penyusunan Rencana Pelaksanaan Penelitian (RPP), pengembangan instrumen tes berdasarkan indikator berpikir kritis, serta uji coba instrumen yang terdiri atas uji validitas dan reliabilitas. Tahap pelaksanaan terdiri atas pemberian pre-test, pelaksanaan pembelajaran inkuiri, dan pemberian post-test.

Analisis data yang dilakukan terdiri atas uji prasyarat yaitu uji normalitas Kolmogorov-Smirnov dan uji homogenitas levene's test, kemudian dilakukan uji hipotesis menggunakan uji anakova. Analisis data dilakukan dengan bantuan aplikasi SPSS 16.0.

\section{HASIL DAN PEMBAHASAN}

Hasil Pretest dan Posttest

Rerata nilai pretest dan posttest kedua kelas tersebut disajikan dalam Gambar 1.

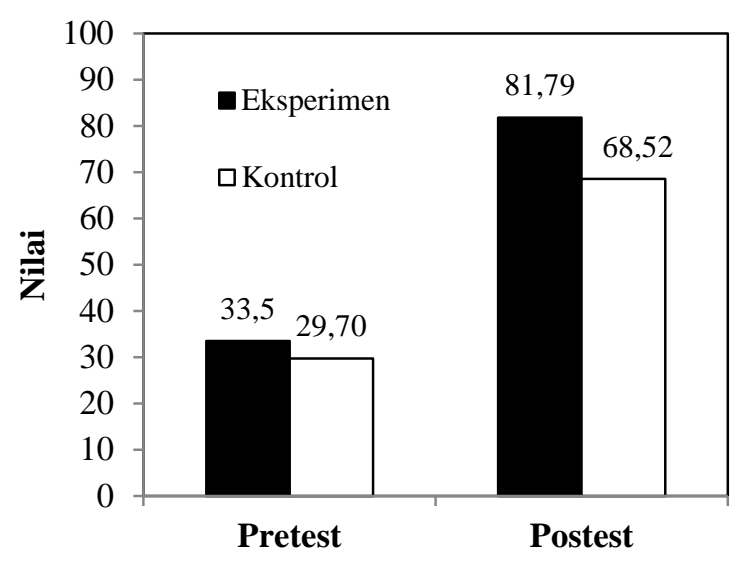

Gambar 1. rerata Nilai Pretest dan Posttest

Berdasarkan data di atas, diketahui bahwa nilai pretest siswa kelas kontrol dan kelas eksperimen memiliki selisih yang cukup kecil, sehingga tidak berbeda jauh. Kemudian setelah diberikan perlakuan yang berbeda, nilai posttest siswa kelas eksperimen dan kelas kontrol memiliki selisih yang relatif tinggi. Perbedaan tersebut terjadi karena adanya pengaruh diterapkannya model pembelajaran inkuiri, yang kemudian dibuktikan melalui uji hipotesis anakova. 


\section{Hasil uji hipotesis}

Hipotesis dari penelitian ini adalah sebagai berikut.

$\mathrm{H}_{\mathrm{o}}$ : Penerapan model pembelajaran inkuiri tidak berpengaruh terhadap keterampilan berpikir kritis siswa kelas XI MIA MAN 2 Mataram tahun ajaran 2019/2020.

$H_{a}$ : Penerapan model pembelajaran inkuiri berpengaruh terhadap keterampilan berpikir kritis siswa kelas XI MIA MAN 2 Mataram tahun ajaran 2019/2020.

Uji hipotesis yang dilakukan adalah uji anakova (analisis kovarian) yang merupakan gabungan dari uji komparatif dan uji korelasional. Data dianalisis dengan bantuan aplikasi SPSS 16.0. Sebelum melakukan uji hipotesis dengan anakova, data harus diverifikasi untuk mengetahui apakah sudah memenuhi persyaratan analisis.

\section{Hasil verifikasi data}

1. Ada hubungan linier antara kovarian dengan variabel terikat. Hubungan ini dibuktikan dengan analisis korelasi. Hasil analisis korelasi disajikan pada Tabel 2 berikut.

Tabel 1. Hasil Verifikasi Korelasi antara Kovariat dengan Variabel Terikat

\begin{tabular}{llll}
\hline Variabel & & $\begin{array}{l}\text { Nilai } \\
\text { Postest }\end{array}$ & $\begin{array}{l}\text { Nilai } \\
\text { Pretest }\end{array}$ \\
\hline Nilai_Postest Pearson & 1 & 0,444 \\
& Correlation & & \\
& Signifikansi (p) & & 0,000 \\
$\mathrm{~N}$ & 78 & 78 \\
\hline Nilai_Pretest & Pearson & 0,444 & 1 \\
Correlation & & \\
Signifikansi (p) & 0,000 & \\
$\mathrm{~N}$ & 78 & 78 \\
\hline
\end{tabular}

Tabel 1 menunjukkan bahwa terdapat korelasi yang signifikan antara kovariat dengan variabel terikat yaitu antara nilai pretest dengan nilai posttest $(\mathrm{r}=0,444 ; \mathrm{p}=0,00<0,05)$. Adanya korelasi ini menunjukkan alasan yang kuat untuk menempatkan nilai pretest sebagai kovariat.

2. Kemiringan garis regresi antar kelompok harus sama. Kesamaan kemiringan garis ini dibuktikan dengan tidak adanya interaksi antara kovarian dengan variabel bebas. Hasil analisis interaksi disajikan pada Tabel 2.

Berdasarkan Tabel 2 hasil verifikasi menunjukkan bahwa tidak ada interaksi antara kelompok/kelas penelitian (kelas eksperimen dan kontrol) sebagai variabel bebas dengan nilai pretest sebagai kovariat dibuktikan dengan nilai signifikansi (p) sebesar $0,428(\mathrm{~F}=0,634 ; \mathrm{p}>0,05)$.
Tabel 2. Hasil verifikasi interaksi antara kovariat dengan variabel bebas

\begin{tabular}{lll}
\hline Variabel & F & $\begin{array}{l}\text { Signifikansi } \\
(\mathrm{p})\end{array}$ \\
\hline Kelompok & 1,932 & 0,169 \\
$\begin{array}{l}\text { Nilai pretest } \\
\text { Kelompok*Nilai } \\
\text { pretest }\end{array}$ & 9,891 & 0,002 \\
\hline
\end{tabular}

\section{Hasil uji anakova}

Hasil akhir uji anakova dengan bantuan SPSS 16.0 disajikan pada Tabel 3 dan Tabel 4 berikut.

Tabel 3. Hasil Analisis Deskriptif Uji Anakova

\begin{tabular}{llll}
\hline Kelas & $\begin{array}{l}\text { Rerata Posttest } \\
\text { Terkoreksi Pretest }\end{array}$ & $\begin{array}{l}\text { Standar } \\
\text { Deviasi }\end{array}$ & N \\
\hline Eksperimen & 81,785 & 6,569 & 40 \\
Kontrol & 68,519 & 13,449 & 38 \\
Total & 75,322 & 12,382 & 78 \\
\hline
\end{tabular}

Tabel 3 menunjukkan bahwa rerata nilai posttest kelas eksperimen $(\mathrm{R}=81,785$; $\mathrm{SD}=6,569)$ lebih tinggi dibandingkan kelas kontrol $(\mathrm{R}=68,519$; $\mathrm{SD}=13,449$ ).

Tabel 4. Hasil Uji Anakova

\begin{tabular}{llll}
\hline Variabel & $\mathrm{F}$ & $\begin{array}{l}\text { Signifikansi } \\
(\mathrm{p})\end{array}$ & $\begin{array}{l}\text { Partial } \\
\text { Eta } \\
\text { Squared }\end{array}$ \\
\hline $\begin{array}{l}\text { Kelas } \\
\text { perlakuan }\end{array}$ & 28,328 & 0,000 & 0,274 \\
$\begin{array}{l}\text { Nilai } \\
\text { Pretest }\end{array}$ & 16,279 & 0,000 & 0,178 \\
\hline
\end{tabular}

Tabel 4 menunjukkan terdapat perbedaan keterampilan berpikir kritis antara kelas kontrol dan kelas eksperimen setelah diterapkannya model pembelajaran inkuiri $(\mathrm{F}=28,328 ; \mathrm{p}=0,00<0,05)$. Nilai pretest berpengaruh secara signifikan terhadap nilai posttest $(\mathrm{F}=16,279 ; \mathrm{p}=0,00<0,05)$. terhadap nilai posttest $(\mathrm{F}=16,279 ; \mathrm{p}=0,00<0,05)$. Partial eta squared menunjukkan estimasi besarnya sumbangan efektif. Sumbangan efektif model pembelajaran inkuiri terhadap peningkatan keterampilan berpikir kritis siswa kelas eksperimen adalah 27,4 persen. Sumbangan efektif nilai pretest terhadap posttest (keterampilan berpikir kritis siswa) adalah 17,8 persen.

Berdasarkan kedua hasil di atas $(\mathrm{F}=$ 28,328; $\mathrm{F}=16,279$; dengan nilai $\mathrm{p}=0,00<0,05)$, maka $\mathrm{H}_{0}$ ditolak dan $\mathrm{H}_{a}$ diterima, yang berarti bahwa model pembelajaran inkuiri berpengaruh terhadap 
keterampilan berpikir kritis siswa kelas XI MIA MAN 2 Mataram tahun ajaran 2019/2020.

\section{Pembahasan}

Penelitian yang telah dilaksanakan dengan menerapkan model pembelajaran inkuiri dengan materi pokok sel pada siswa kelas XI MIA di MAN 2 Mataram menunjukkan adanya pengaruh model pembelajaran tersebut terhadap keterampilan berpikir kritis. Pengaruh ini dibuktikan oleh hasil uji anakova (Tabel 4) yang menunjukkan nilai signifikan (p) 0,00 (p<0,05). Persentase pengaruh model pembelajaran inkuiri terhadap keterampilan berpikir kritis siswa adalah sebesar 27,4 persen. Adapun pengaruh yang diberikan berupa pengaruh positif, dapat dilihat dari hasil $\mathrm{F}$ hitung bernilai positif $(F=28,328)$. Berarti bahwa model pembelajaran inkuiri berpengaruh dalam meningkatkan keterampilan berpikir kritis siswa.

Uji anakova merupakan gabungan antara uji komparatif (anova) dan uji korelasional (regresi). Anova (Analysis of variance) digunakan untuk menguji perbandingan keterampilan berpikir kritis siswa kelas ekserimen dengan kelas kontrol ditinjau dari pemberian perlakuan berupa penerapan model pembelajaran inkuiri. Uji regresi digunakan untuk memprediksi keterampilan berpikir kritis siswa berdasarkan pengetahuan awalnya. Hasil uji anakova dari penelitian ini menunjukkan adanya perbedaan dan hubungan sekaligus. Terdapat perbedaan keterampilan berpikir kritis antara kelas eksperimen dengan kelas kontrol dan terdapat hubungan linier antara pengetahuan awal (pretest) dengan keterampilan berpikir kritis siswa setelah diberikan perlakuan

Terdapat perbedaan keterampilan berpikir kritis antara kelas eksperimen dengan kelas kontrol. Dibuktikan dengan hasil uji anakova ( $\mathrm{p}=0,00<$ 0,05). Hasil analisis deskriptif juga menunjukkan bahwa rata-rata keterampilan berpikir kritis siswa kelas eksperimen $(\mathrm{R}=81,785)$ lebih tinggi dibandingkan siswa kelas kontrol $(\mathrm{R}=68,519)$. Perbedaan tersebut terjadi karena diterapkannya model pembelajaran inkuiri pada kelas eksperimen, sedangkan kelas kontrol diterapkan model pembelajaran konvensional berupa ceramah dan tanya jawab.

Model pembelajaran inkuiri berpengaruh terhadap keterampilan berpikir kritis siswa. Pada kelas eksperimen dengan penerapan model pembelajaran inkuiri terbimbing menekankan kerja aktif dan proses berpikir siswa. Pembelajaran yang diterapkan pada kelas kontrol melalui penerapan model pembelajaran konvensional dengan metode ceramah bervariasi. Peran guru lebih dominan dibandingkan dengan kegiatan siswa sehingga cenderung membuat siswa bersikap pasif dalam proses pembelajaran [5].

Rata-rata nilai keterampilan berpikir kritis siswa yang diperoleh pada kelas eksperimen lebih tinggi dari pada kelas kontrol. Sejalan dengan hasil penelitian oleh Masitoh, Marjono, dan Ariyanto [6] menunjukkan persentase keterampilan berpikir kritis siswa pada kelas yang diterapkan model pembelajaran inkuiri terbimbing sebesar 81,44\%, lebih tinggi dibandingkan dengan siswa pada kelas yang diterapkan pembelajaran konvensional berupa metode ceramah yaitu $75,97 \%$. Hal ini dapat terjadi karena melalui pembelajaran inkuiri terbimbing, guru mengajak siswa untuk terlibat aktif dalam pembelajaran. Siswa diajak aktif berpikir mengenali masalah, mengungkapkan gagasan-gagasan pemecahan masalah, merancang percobaan sendiri untuk menjawab masalah yang dihadapi, melakukan percobaan untuk mencari jawaban, menganalisis dan menginterpretasi data, menemukan jawaban, serta mendiskusikan hasilnya sampai pada penyusunan kesimpulan. Inkuiri terbimbing mampu melatih keterampilan intelektual, berpikir kritis, dan mampu memecahkan masalah secara ilmiah. Proses pemecahan masalah dikaitkan dengan permasalahan sehari-hari, sehingga siswa memiliki kesempatan untuk belajar memecahkan masalah yang dihadapinya di kehidupan sehari-hari dan masalah yang berasal dari fenomena-fenomena nyata yang mengakibatkan siswa akan terlibat dalam perilaku berpikir [7].

Sejalan dengan penelitian Azizmalayeri [8] dan Fuad, dkk [9] yang membuktikan bahwa pembelajaran inkuiri berkontribusi dalam meningkatkan keterampilan berpikir kritis. Masioth, dkk [6] mengungkapkan bahwa pada prinsipnya keseluruhan proses pembelajaran inkuiri terbimbing membantu siswa menjadi mandiri, percaya diri, dan yakin terhadap kemampuan intelektualnya sendiri untuk terlibat secara aktif. Guru membimbing siswa dalam pembelajaran sehingga diharapkan mampu mengembangkan keterampilan berpikir kritis siswa melalui sintaks inkuiri terbimbing. Rangkuti dan Sani [10] mengungkapkan bahwa terdapat perbedaan keterampilan berpikir kritis siswa antara model pembelajaran inkuiri dan direct teaching dengan rata-rata lebih tinggi pada kelompok inkuiri dibandingkan direct teaching.

Sintaks inkuiri terbimbing meliputi enam tahapan yaitu menyajikan pertanyaan atau masalah, membuat hipotesis, merancang percobaan, melakukan percobaan, mengumpulkan dan menganalisis data serta membuat kesimpulan. Pembelajaran inkuiri terbimbing menekankan pada proses berpikir yang bersandarkan pada proses belajar dan hasil belajar serta mengembangkan seluruh potensi siswa termasuk keterampilan inkuiri [7]. Berdasarkan penelitian Hasruddin [11] bahwa penerapan pembelajaran inkuiri dapat memberdayakan kemampuan berpikir siswa sehingga dapat memaksimalkan keterampilan berpikir kritis. Setiap tahapan dari sintaks inkuiri terbimbing mampu mengembangkan keterampilan berpikir kritis siswa. 
Pembelajaran inkuiri terbimbing dapat mengkondisikan siswa untuk berpikir kritis, dari observasi yang siswa lakukan dapat memunculkan suatu kesimpulan sehingga siswa dapat menemukan konsep sendiri secara ilmiah. Konsep tersebut yang akan menjadi pengetahuan kognitif siswa. Keterampilan berpikir kritis dapat melatihkan aspek kognitif, afektif dan psikomotorik siswa [4]. Sejalan dengan penelitian Ajwar [12], bahwa berpikir kritis siswa dapat mempengaruhi hasil belajar siswa. Ajwar [12] menjelaskan bahwa siswa yang berpikir kritis akan tampak pada saat menganalisis permasalahan untuk menentukan solusi permasalahan serta menentukan keterkaitan dengan konsep materi biologi. Berpikir kritis memacu struktur kognitif setiap siswa untuk menangkap ideide, konsep-konsep dan mengorganisasikan pengetahuan yang dimiliki untuk mengasah perkembangan kecakapan dan kesiapan berpikir siswa.

Artayasa, dkk [13] menjelaskan bahwa para mahasiswa yang dibelajarkan dengan inkuiri terbimbing mengakui bahwa model pembelajaran yang diterapkan cukup menarik dan interaktif karena dosen memberikan pertanyaan eksperimental yang memotivasi mahasiswa untuk berdiskusi. Model pembelajaran inkuiri dirancang dengan tujuan untuk mengembangkan siswa supaya memiliki keterampilan ilmiah, dan juga memotivasi melalui keterlibatan langsung dalam proses pembelajaran, mengembangkan kemampuan penelitian yang berdampak pada tercapainya hasil pembelajaran seperti berpikir kritis, kemampuan penelitian, tanggung jawab terhadap pembelajarannya, perkembangan intelektual, dan kedewasaan. Pembelajaran inkuiri selain berorientasi kepada hasil belajar juga berorientasi pada proses belajar. Tujuannya adalah untuk mengembangkan kemampuan berpikir. Keterampilan berpikir kritis siswa dapat dilakukan dengan selalu bertanya dan mempertanyakan berbagai fenomena yang sedang dipelajari. Dalam pembelajaran inkuiri, belajar bukan hanya mengingat sejumlah fakta, akan tetapi belajar adalah proses berpikir [4].

Model pembelajaran inkuiri memberikan peluang kepada siswa untuk memaksimalkan aktivitas belajarnya. Fungsi dan tugas guru hanya sebagai fasilitator dan mediator dalam pembelajaran. Guru harus mampu menciptakan pembelajaran yang dapat mengikutsertakan siswa secara aktif dalam setiap kegiatan pembelajaran. Keaktifan siswa dalam proses pembelajaran akan menciptakan interaksi yang intensif antara guru, siswa, dan, materi pelajaran. Hal ini akan menciptakan suasana pembelajaran yang kondusif, dan memberikan peluang kepada masing-masing siswa dapat melibatkan kemampuannya secara optimal, sehingga dalam pembelajaran siswa akan dapat meningkatkan keterampilan berpikir kritisnya.
Pembelajaran langsung lebih menekankan informasi konsep dan prinsip, latihan soal, dan tes. Pembelajaran langsung hanya menekankan pada pemenuhan konten, tanpa memberikan waktu yang cukup kepada siswa untuk merefleksikan materi yang dipresentasikan, menghubungkannya dengan pengetahuan sebelumnya, atau mengaplikasikannya dalam kehidupan sehari-hari. Pembelajaran langsung tidak dimaksudkan untuk mencapai hasil belajar sosial atau kemampuan berpikir tinggi, namun bertujuan untuk menuntaskan hasil belajar siswa yaitu penguasaan pengetahuan yang distrukturisasi dengan baik dan pengetahuan keterampilan. Dalam pembelajaran langsung siswa hanya menerima apa yang telah disampaikan oleh guru. Pembelajaran seperti ini mengakibatkan pikiran siswa tidak berkembang dengan baik, karena siswa tidak diberikan kesempatan untuk mengeksplorasi kemampuannya [3].

Selain dari kelebihan yang dimiliki, model pembelajaran inkuiri terbimbing memiliki beberapa kelemahan dalam pelaksanaannya. Berdasarkan proses pembelajaran yang telah dilaksanakan selama penelitian, keahlian guru dalam mengalokasikan waktu sangat penting. Sebab, proses mencari dan mengumpulkan informasi oleh siswa relatif memakan waktu. Solusinya yaitu dengan cara guru menginformasikan materi pelajaran yang akan didiskusikan pada pertemuan sebelumnya sehingga siswa dapat mempelajarinya di rumah sebagai pengetahuan awalnya. Pengetahuan awal tersebutlah yang akan mempermudah siswa untuk mengumpulkan informasi dalam kegiatan pembelajaran di kelas. Jumlah siswa yang relatif banyak juga menjadi kendala bagi guru untuk mengontrol dan memastikan siswa terlibat dalam pembelajaran inkuri. Oleh sebab itu, siswa dapat dibagi menjadi beberapa kelompok kecil (3-4 orang), di mana setiap siswa diberi tanggung jawab masing-masing dalam kelompoknya.

Terdapat hubungan linier antara pengetahuan awal (pretest) dengan keterampilan berpikir kritis siswa setelah diberikan perlakuan (Tabel 4). Sumbangan efektif nilai pretest terhadap posttest (keterampilan berpikir kritis siswa) adalah $17,8 \%$. Semakin tinggi nilai pretest maka semakin tinggi pula nilai posttest. Grafik pada Gambar 1 menunjukkan bahwa nilai pretest siswa kelas eksperimen lebih tinggi dibandingkan kelas kontrol, begitu pula nilai posttest siswa kelas eksperimen lebih tinggi dibandingkan kelas kontrol.

Hal tersebut menunjukkan bahwa pengetahuan awal siswa (pretest) sebagai kovariat dapat memprediksi besarnya keterampilan berpikir kritis siswa (posttest). Sesuai dengan tujuan uji regresi yaitu untuk mengetahui seberapa jauh sebuah variabel bebas/kovarian mampu memprediksi besarnya variabel terikat. Fokus penelitian ini hanya pada satu variabel bebas saja yaitu model pembelajaran inkuiri, tetapi terdapat variabel lain 
yang mempengaruhi keterampilan berpikir kritis yaitu pengetahuan awal siswa. Sehingga pengetahuan awal siswa (pretest) ditempatkan sebagai variabel kontrol atau kovarian.

Sejalan dengan hasil penelitian Handayani [14], bahwa pengetahuan awal secara parsial berpengaruh terhadap hasil belajar sebesar $28,8 \%$ sedangkan sisanya sebesar $71,2 \%$ dipengaruhi oleh variabel lain. Hikmah [15] juga mengungkapkan bahwa besarnya pengaruh kompetensi guru dan pengetahuan awal terhadap motivasi belajar adalah sebesar 0,327 atau sebesar $32,7 \%$, artinya sebesar $32,7 \%$ motivasi belajar dapat dijelaskan oleh kompetensi guru dan pengetahuan awal. Sisanya sebesar $67,3 \%$ merupakan pengaruh variabel lain yang tidak dijelaskan dalam model. Penelitian oleh Pamungkas dan Setyani [16] menjelaskan bahwa terdapat hubungan yang signifikan antara pengetahuan awal dan self esteem matematis terhadap kemampuan berpikir logis mahasiswa.

Pengetahuan awal berpengaruh secara langsung dan tak langsung dalam proses pembelajaran. Pengaruh secara langsung yang dimaksud adalah pengetahuan awal dapat mempermudah proses pembelajaran dan mengarahkan hasil belajar yang lebih baik. Pengaruh tidak langsung, yaitu pengetahuan awal dapat mengoptimalkan kejelasan materi-materi pelajaran dan meningkatkan efisiensi penggunaan waktu belajar dan pembelajaran. Pembelajaran yang berorientasi pada pengetahuan awal akan memberikan dampak pada proses dan perolehan belajar yang memadai [14].

Apabila siswa mempunyai banyak pengetahuan awal yang tentunya dijadikan landasan dasar untuk pembelajaran berikutnya dan pasti akan mempengaruhi siswa untuk disiplin dalam belajar baik itu di sekolah maupun dirumah serta didukung dengan iklim komunikasi kelas yang nyaman dan kondusif, sehingga akan timbul kekompakan dan komunikasi yang baik antara siswa dengan guru maupun antara sesama siswa, tentunya akan berpengaruh terhadap hasil belajar siswa yaitu dengan mendapatkan nilai yang tinggi selama pembelajaran [14].

Berdasarkan hasil verifikasi data anakova, diketahui bahwa tidak ada interaksi antara kovarian dengan variabel bebas, yaitu tidak ada interaksi antara perlakuan berupa penerapan model pembelajaran inkuiri dengan nilai pretest. Hal tersebut berarti nilai pretest siswa baik pada kelas eksperimen maupun kontrol tidak ada hubungannya dengan pemberian perlakuan.

Insturmen penilaian keterampilan berpikir kritis yang digunakan dalam penelitian ini berupa instrumen tes uraian/essay. Zubaidah, Aloysius, dan Mistianah [17] mengembangkan asesmen berpikir kritis terintegrasi tes essay, karena bentuk essay mendorong siswa untuk menunjukkan respon atau jawaban daripada hanya memilih jawaban. Beberapa ahli pendidikan menggunakan tes essay karena mempunyai potensi untuk mengungkap kemampuan siswa untuk mengungkapkan alasan, menyusun, menganalisis, mensintesis, dan mengevaluasi. Beberapa kelebihan tes essay adalah 1) dapat digunakan untuk menilai keterampilan berpikir tingkat tinggi atau keterampilan berpikir kritis, 2) dapat mengevaluasi proses berpikir dan bernalar siswa, dan 3) memberikan pengalaman autentik.

Instrumen tes essay disusun berdasarkan indikator berpikir kritis yang disusun oleh Ennis [18] yang terangkum dalam 5 kelompok keterampilan berpikir, yaitu memberikan penjelasan sederhana (elementary clarification), membangun keterampilan dasar (basic support), menyimpulkan (interfence), membuat penjelasan lebih lanjut (advance clarification), serta strategi dan taktik (strategy and tactics). Instrumen tes tersebut diberikan kepada siswa dalam bentuk pretest dan posttest, baik untuk siswa kelas eksperimen maupun kontrol.

Facione [19] mengungkapkan bahwa keterampilan berpikir kritis meliputi enam aspek yaitu interpretation, analysis, inference, explanation, evaluation dan self-regulation. Interpretation merupakan kemampuan untuk memahami dan menjelaskan dan memberi makna data atau informasi. Analysis merupakan kemampuan untuk mengidentifikasi hubungan dari informasi yang digunakan untuk menyampaikan atau mengekspresikan pendapat. Inference merupakan kemampuan untuk mengidentifikasi dan memilih unsur-unsur yang diperlukan untuk membuat kesimpulan yang beralasan, membentuk perkiraan dan hipotesis untuk mempertimbangkan informasi yang relevan dan mengembangkan sebagai akibat dari data atau bukti. Evaluation merupakan kemampuan untuk menguji kebenaran, menilai pernyataan atau pendapat yang diterima baik diri sendiri maupun orang lain. Explanation merupakan kemampuan siswa untuk menjelaskan atau menyatakan pernyataan maupun pendapat berdasarkan bukti, metodologi dan konsep. Selfregulation merupakan kemampuan untuk mengatur keberadaan diri sendiri dalam menghadapi pemecahan masalah.

Konteks interpretation dalam soal keterampilan berpikir kritis yang diberikan, siswa dituntut untuk mengelompokkan dan memberikan penjelasan berdasarkan informasi yang diperoleh seperti gambar, video, atau bentuk informasi lainnya tentang sel. Konteks analysis dalam soal yaitu siswa diminta untuk menganalisis pernyataan mengenai sel sebagai unit struktural dan fungsional terkecil dari makhluk hidup. Konteks inference dalam soal yang diberikan, siswa diminta untuk menginferensi dampak osmosis terhadap sel darah merah, serta dampak mitosis terhadap tubuh makhluk hidup. Konteks evaluation dalam soal, siswa dituntut untuk menilai pernyataan mana yang tepat dan tidak tepat mengenai teori sel. Konteks explanation dan self- 
regulation dalam soal keterampilan berpikir kritis yakni, siswa dituntut untuk menyatakan hasil dan argumen yang mendukung mengenai sintesis protein, dan dampaknya kesalahan penerjemahan asam amino terhadap makhluk hidup.

Hasil penelitian oleh Masitoh, dkk [6] menunjukkan bahwa penerapan model pembelajaran inkuiri terbimbing dapat meningkatkan persentase capaian indikator berpikir kritis. Pencapaian tersebut antara lain $89,84 \%$ untuk aspek interpretation, $53,13 \%$ untuk aspek analysis, 75,78\% untuk aspek inference, 94,53\% untuk aspek untuk aspek eksplanation, 82,03\% untuk aspek evaluation, serta $92,97 \%$ untuk aspek self-regulation. Persentase capaian tersebut lebih tinggi dibandingkan kelas yang tidak menggunakan model pembelajaran inkuiri.

Berdasarkan uraian di atas, baik dilihat dari segi teoritis maupun penyajian pembelajaran, terbukti bahwa pembelajaran inkuiri berpengaruh dalam meningkatkan keterampilan berpikir kritis siswa.

\section{KESIMPULAN}

Hasil analisis data $(\mathrm{F}=28,328 ; \mathrm{p}=0,00<$ 0,05) menunjukkan bahwa $\mathrm{H}_{0}$ ditolak dan $\mathrm{H}_{\mathrm{a}}$ diterima, yang berarti model pembelajaran inkuiri berpengaruh terhadap keterampilan berpikir kritis siswa kelas XI MIA MAN 2 Mataram tahun ajaran 2019/2020. Berdasarkan hasil analisis data dan pembahasan dapat disimpulkan bahwa model pembelajaran inkuiri berpengaruh dalam meningkatkan keterampilan berpikir kritis siswa.

\section{DAFTAR PUSTAKA}

[1] Winarni, E. W. (2009). Mengajar IPA Secara Bermakna. Bengkulu: Unib Press.

[2] Setyorini, U., Sukiswo, S., \& Subali, B. (2011). Penerapan Model Problem Based Learning untuk Meningkatkan Kemampuan Berpikir Kritis Siswa SMP. Jurnal Pendidikan Fisika Indonesia , 52-56.

[3] Royani, I., Mirawati, B., \& Jannah, H. (2018). Pengaruh Model Pembelajaran Langsung Berbasis Praktikum Terhadap Keterampilan Proses Sains dan Kemampuan Berpikir Kritis Siswa. Prisma Sains Jurnal Pengkajian Ilmu dan Pembelajaran Matematika dan IPA IKIP Mataram , 6 (2), 46-55.

[4] Jufri, A. W. (2013). Belajar dan Pembelajaran Sains. Bandung: Penerbit Pustaka Reka Cipta.

[5] Sanjaya, W. (2006). Strategi Pembelajaran Berorientasi Standar Proses Pendidikan. Jakarta: Kencana Prenada Media Group.

[6] Masitoh, I. D., Marjono, \& Ariyanto, J. (2017). Pengaruh Model Pembelajaran Inkuiri Terbimbing Terhadap Kemampuan Berpikir Kritis Kelas X MIA pada Materi Pencemaran
Lingkungan di Surakarta. Bioedukasi , 10 (1), 71-79.

[7] Anam, K. (2016). Pembelajaran Berbasis Inkuiri: Metode dan Aplikasi. Yogyakarta: Pustaka Pelajar.

[8] Azizmalayeri, K., Mirshahjafari, E., Sharif, M., Asgari, M., \& Omidi, M. (2012). The Impact of Guided Inquiry Methods of Teaching on the Critical Thinking of High School Student. Journal of Education and Practice , 3 (10), 4247.

[9] Fuad, N. M., Zubaidah, S., Mahanal, S., \& Suarsini, E. (2017). Improving Junior High Schools' Critical Thinking Skills Based on Test Three Different Models of Learning. International Journal of Instruction , 10 (1), 101116.

[10] Rangkuti, M. A., \& Sani, R. A. (2018). Analisis Kemampuan Berpikir Kritis Menyelesaikan Masalah Fisika dan Gaya Belajar Siswa pada Pembelajaran dengan Model Pemeblajaran Inkuiri. Jurnal Inovasi Pembelajaran Fisika, 82-86.

[11] Hasruddin. (2009). Memaksimalkan Kemampuan Berpikir Kritis Melalui Pendekatan Kontekstual. Diakses pada 18 Juni, 2019, dari Jurnal Tabula Rasa: http//digilib.unimed.ac.id/public/ UNIMEDArticle-24572-Hasruddin.pdf.

[12] Ajwar, M. (2015). Pengaruh Pembelajaran Inkuiri Terbimbing dan Inkuiri Bebas Termodifikasi Terhadap Prestasi Belajar Ditinjau Dari Berpikir Kritis dan Kedisiplinan Belajar Siswa Kelas X MIA SMA Negeri 8 Surakarta Tahun Pelajaran 2014/2015. Jurnal Inkuiri , 4 (3), 127-135.

[13] Artayasa, I. P., Susilo, H., Lestari, U., Indriwati, S. E. (2017). The Effectiveness of The Three Levels of Inquiry in Improving Teacher Training Students' Science Process Skills. Journal of Baltic Science Education, 16 (6), 908-918.

[14] Handayani, V. T. (2015). Pengaruh Pengetahuan Awal, Kedisiplinan Belajar, dan Iklim Komunikasi Kelas Terhadap Hasil Belajar Produktif Akuntansi Siswa Kelas XI Jurusan Akuntansi SMK Negeri 3 Bangkalan. Jurnal Ekonomi Pendidikan dan Kewirausahaan , 3 (1), 91-102.

[15] Hikmah, N. (2018). Pengaruh Kompetensi Guru dan Pengetahuan Awal Siswa terhadap Motivasi Belajar dan Implikasinya terhadap Hasil Belajar Ekonomi Siswa. Indonesian Journal Of Economics Education, 1 (1), 9-16.

[16] Pamungkas, A. S., \& Setiani, Y. (2017). Peranan Pengetahuan Awal dan Self Esteem 
J. Pijar MIPA, Vol. 14 No. 3, September 2019:154-161

Matematis Terhadap Kemampuan Berpikir Logis Mahasiswa. Kreano , 8 (1), 61-68.

[17] Zubaidah, S., Aloysius, D. C., \& Mistianah. (2015). Asesmen Berpikir Kritis Terintegrasi Tes Essay. Symbion: Symposium on Biology Education (pp. 200-213). Yogyakarta: Program Studi Pendidikan Biologi Universitas Ahmad Dahlan.

[18] Ennis, R. H. (1985). Goals for A Critical Thinking Curriculum, Developing Minds: A Resource Book for Teaching Thinking. Virginia: ASDC.

[19] Facione, P. A. (2013). Critical Thinking: What It Is and Why It Counts. Insight Assessment, 127. 